\title{
Administrative Judicial Decisions as a Hybrid Argumentative Activity Type
}

\author{
H. José Plug \\ University of Amsterdam \\ Department of Speech Communication, \\ Argumentation Theory, and Rhetoric \\ Spuistraat 134, \\ 1012 VB Amsterdam \\ The Netherlands \\ h.j.plug@uva.nl
}

\begin{abstract}
This article focuses on strategic manoeuvring that takes place in Dutch administrative judicial decisions. These decisions may be seen as a distinct argumentative activity type. Starting from the characteristics that traditionally are pertinent to this activity type, I will explore how implications of current discussions on the changing task of the administrative judge may become manifest in the judge's strategic manoeuvring by means of the presentation of argumentation and the introduction of additional standpoints. The case study of Dutch administrative law serves to demonstrate what consequences changing institutional demands may have for the starting points of the analysis of argumentation in judicial decisions.
\end{abstract}

Résumé: Cet article se concentre sur les manœuvres stratégiques qui se déroulent dans les décisions judiciaires administratives néerlandaises. On peut considérer ces décisions comme un type d'activité argumentative distincte. A partir des caractéristiques qui sont traditionnellement pertinentes pour ce type d'activité, je vais explorer comment les implications des discussions courantes sur la tâche changeante du juge administratif peuvent se manifester dans la manœuvre stratégique du juge au moyen de la présentation d'argumentation et d'introduction de points de vue supplémentaires. L'étude de cas $\mathrm{du}$ droit administratif néerlandais sert à démontrer les conséquences que l'évolution des exigences institutionnelles peut avoir sur les points de départ d'analyse d'argumentation dans les décisions judiciaires.

Keywords: activity type, legal argumentation, institutional point, judicial advice, mediator, multiple roles, obiter dictum

\section{Introduction}

In order to analyse argumentation as it takes part in a specific communicative practice, the analyst whose aim it is to critically evaluate situated argumentative acting, should take into account the institutional conventions of that particular communicative practice. The way in which institutional conventions of the legal 
domain should be taken into account for the analysis of argumentation in judicial decisions from a pragma-dialectical perspective, has been the central focus of studies by, amongst others, Feteris (1989), Kloosterhuis (2002) and Plug (2000). These studies, however, came into being before van Eemeren and Houtlosser $(2006,2010)$ developed the extended pragmadialectical argumentation theory by including a rhetorical dimension that provided for the analysis of strategic manoeuvring. To this rhetorical extension, van Eemeren (2010, p. 138-146) added a more defined and detailed approach to account for the communicative practices in which strategic manoeuvring takes place. In this approach, different communicative activity types as they manifest themselves in reality are defined by the goals that are pursued in realizing their institutional point (the institutional rationale), their conventionalization, and the main properties of their format. With regard to these three defining components, considerable differences may be observed, depending on the communicative domain in which the discourse takes place.

Communicative activity types in the legal domain, compared to activity types in other communicative domains such as the political or the medical domain, can be regarded as more strictly conventionalised. Starting points and procedures are laid down in procedural and substantive law. This does not mean, however, that the defining components as they manifest themselves in a communicative domain should be considered as characteristics of a communicative activity type that are absolute or static. As a result of, for example, discussions in society, new legislation or scientific insights, the institutional point of an activity type may need to be revised. The institutional point of medical consultation, for instance, has evolved under the influence of a debate on the doctor-patient relationship. Nowadays, the institutional point of medical consultation can be regarded as convincing the patient of an appropriate medical advice. Such a revision may consist of a modification of the original institutional point or of an extension of the institutional point to a multiple institutional point. Due to changes with regard to the institutional point, the goal, the conventionalization and the main properties of a format may be altered as well. The importance of including these changes in the characterization of the activity type does not only pertain to the analysis and the evaluation in general of the argumentation, it may also be relevant for researching the argumentative patterns in these texts. According to van Eemeren and Garssen (2013, p. 7) such an argumentative pattern will consist of a particular constellation of argumentative moves in which in a particular kind of argumentation structure a 
particular combination of argument schemes is exploited in defense of a particular type of standpoint.

In this contribution I will demonstrate how conventions in the legal communicative domain may change and what consequences these changes may have for the characterisation of the communicative activity type. The activity type I will discuss is that of judicial decisions that are produced by the Dutch administrative court. The changes that are discussed concern the role of the administrative judge and how these changes may influence the institutional point of (administrative) judicial decisions.

In section 2, I will first sketch the communicative activity type of administrative judicial decisions as it is formally institutionalized by means of legal procedural rules. In section 3, I will discuss the way in which altered perspectives on the demands that are made on the administrative judge may affect the conception of the judge's role. Subsequently, in section 4 and 5, I will demonstrate by means of examples from case law how the altered role of the judge may become manifest in judicial decisions. In section 6, I will discuss how changes in the conception of the judge's role may have their influence on the formulation of the institutional point and hence on (the analysis of) the argumentation.

\section{The activity type of administrative judicial decisions}

The communicative activity type of administrative judicial decisions traditionally refers to motivated, binding decisions by judges in cases pertaining to differences of opinion between citizens and public authorities. Administrative law not only entitles public authorities to govern, but it also limits the scope of its administrative activities. Administrative law safeguards citizens against improper actions on the part of public authorities. As part of administrative law, the law of administrative procedure prescribes the way(s) in which citizens may lodge complaints against government decisions. Once an administrative authority has taken a decision, a disagreeing citizen, in most cases, may lodge a complaint against this ruling at the administrative body in question. If a citizen disagrees with the so-called 'decision on complaint' by the said administrative body, he may contest this decision before the judge in administrative law (the administrative court). The judge, then, has to decide whether or not the (final) ruling by the administrative body is legitimate. Subsequently there are the possibilities of appeal at the Council of State or at the Central Appeals Court. The general provisions of administrative law apply to both the realization of government

(C) H. José Plug. Informal Logic, Vol. 36, No. 3 (2016), pp. 333-348. 
decisions and to the judge's evaluation on decisions on complaint and decisions on appeal. In the context of administrative decisions seen as a communicative activity type, the general provisions of administrative law, therefore, are of considerable importance to the institutional goal(s), the conventions and the specifications of both the argumentation put forward in the decision and in the legal discussion preceding the final ruling.

Taking the outline of argumentative activity types as presented by van Eemeren (2010, p. 143) as a starting point, I characterised (Plug, 2015) the activity type of administrative judicial decisions as follows:

\begin{tabular}{|c|c|c|c|}
\hline $\begin{array}{l}\text { domains of } \\
\text { communicative } \\
\text { activity }\end{array}$ & $\begin{array}{l}\text { general genres } \\
\text { of communica- } \\
\text { tive activity }\end{array}$ & $\begin{array}{l}\text { specific commu- } \\
\text { nicative activity } \\
\text { types }\end{array}$ & $\begin{array}{l}\text { Concrete } \\
\text { speech events }\end{array}$ \\
\hline $\begin{array}{l}{[=\text { more or less }} \\
\text { institutionalized } \\
\text { macro- } \\
\text { contexts] }\end{array}$ & $\begin{array}{l}{[=\text { families of }} \\
\text { conventionalized } \\
\text { communicative } \\
\text { practices] }\end{array}$ & $\begin{array}{l}\text { [= subtypes of } \\
\text { conventionalized } \\
\text { communicative } \\
\text { practices] }\end{array}$ & $\begin{array}{l}{[=\text { instantia- }} \\
\text { tions of com- } \\
\text { municative } \\
\text { activity types] }\end{array}$ \\
\hline $\begin{array}{l}\text { legal } \\
\text { communication }\end{array}$ & adjudication & $\begin{array}{l}\text { Judicial deci- } \\
\text { sions by the } \\
\text { (District) Court } \\
\text { (Administrative } \\
\text { Law) }\end{array}$ & $\begin{array}{l}\text { Dutch judicial } \\
\text { decision [by } \\
\text { the (District) } \\
\text { Court Utrecht } \\
21-12-2012]\end{array}$ \\
\hline
\end{tabular}

Figure 1. An example of a concrete speech event representing a subtype of communicative activity implementing a genre of communicative activity instrumental in the legal communicative domain

Figure 1 illustrates that a contextualised argumentative analysis or evaluation of a concrete speech event such as the judicial decision by the administrative (district) court on December 21, 2012, presupposes a text to be considered as a representation of a particular subtype of (argumentative) communicative activity: the activity type of administrative judicial decisions by the (district) court. This communicative subtype, in its turn, belongs to the domain of legal communication and makes use of the prototypical genre of adjudication.

The institutional point of this communicative subtype can be formulated as providing a binding decision in a difference of opinion about whether a citizen is being treated unlawfully by the actions of an administrative authority. 


\section{Changing demands in administrative law and the role of the judge}

The role of the judge in administrative law, traditionally, focuses on evaluating or testing government decisions. The evaluation, in reaction to the appeal lodged by an interested party, means that a judge examines a decision for its legitimacy. In case the judge is of the opinion that a decision is indeed legitimate, the appeal is denied and the original ruling is maintained. If, however, the judge deems a decision not legitimate, he may declare the appeal well founded and consequently quash the original ruling. The Dutch General Administrative Law Act (chapter 8) states that the administrative body in question is to provide the judge with all written material pertaining to the decision making process, in order to enable the judge to reach a conclusion. Moreover, the parties to the process should be allowed to put forward their standpoints and arguments on the (un)lawfulness of the decision, both verbally and in writing. It is on the basis of these standpoints and arguments that the judge will form his opinion on the administrative ruling.

The difference of opinion between citizens and public authorities for the judge to rule on, is, then, limited by the scope of administrative law. The propositional content of the judge's ultimate standpoint, on the grounds of which he will decide whether or not to allow the appeal, pertains to the lawfulness of the authorities' decision. The judge's speech act with which he will or will not allow the plaintiff's appeal, may be analysed as an assertive-declarative speech act with which the former adopts a positive or a negative standpoint. The speech acts with which the judge justifies his ruling are analysed as assertive speech acts with which he completes the complex speech act of argumentation. ${ }^{1}$

On the occasion of the 2007 evaluation of the General Administrative Law Act, however, the present committee established to evaluate the general provisions of administrative law (the evaluation committee $A w b$ III) recommends to no longer limit the role of the judge in administrative law to providing a ruling as to the lawfulness of a decision. The final evaluative report on project differentiation of tasks in administrative law

\footnotetext{
${ }^{1}$ From a pragma-dialectical perspective, based on the judge's obligation for justification, the decision can be regarded as an assertive speech act in the discussion between the judge and, among others, the parties. At the same time, based on the judge's authority to decide, the speech act can be regarded as a declarative in the discussion between the parties. Discussions in the literature, however, tend to focus on whether a legal decision should be treated as either a declarative or an assertive speech act (see Plug 2000, p. 51).
}

C H. José Plug. Informal Logic, Vol. 36, No. 3 (2016), pp. 333-348. 
[Eindrapport Project Differentiatie van Werkstromen Bestuursrecht] of 2010 and many other publications indicate that judges may be expected to contribute to social preconditions relevant to administrative law, such as speed, cogency, finality and a focus on solutions. The concept of finality refers to the idea that the judge in administrative law reaches a conclusion or understanding that actually ends the underlying conflict or judicial dispute. With reference to this discussion, Marseille $(2009$, p. 67, 2010) indicates that the scope of a difference of opinion between parties may reach beyond the decision against which the original appeal was lodged. The parties' decision to go to court need not be based on the contents of the decision alone, but on the course of the decision-making process as well. As Marseille (2010, p. 222) points out, it is important for judges to distinguish between the decision against which an appeal was lodged on the one hand and the dispute between the parties on the other. The introduction of the New approach to case proceedings [the Nieuwe zaaksbehandeling] is aimed at shedding light, already during the court hearing, on the fact that the difference of opinion is possibly not just about contesting the decision, or even about something other than the decision at hand. The judge could, then, explicitly bring forward the ways in which the law could, or could not solve the conflict, investigate whether there are way(s) in which a solution of the conflict between parties could be solved, irrespective of the outcome of the appeal procedure, and in how far he could contribute to such a solution.

These changes, aimed at achieving a more active role on the part of the judge and at increasing the chances of swift and definitive solutions of cases, have an impact on the complexity of the role judges play. Polak (2010, p. 97), for instance, states that these changes in administrative law have resulted in the judge being allotted the role of mediator in disputes on top of his role as controller. However, if a judge is expected to not only contribute to swift and definitive solutions of legal disputes but also of non-legal disputes between parties, we should, in my opinion, clearly distinguish between his role as the judge who settles a dispute and his role as alternative mediator. ${ }^{2}$ This means that it would be more adequate to distinguish between the following three roles: ${ }^{3}$

\footnotetext{
2 The term 'mediation', as used in law, is a form of alternative dispute resolution (ADR), where a third party, the mediator, assists the parties to negotiate a settlement. Since during the proceedings, the contribution of the judge to a settlement is more limited and differs in some aspects fundamentally from that of a mediator, I use the term 'alternative' mediator.

3 Apart from institutional demands, judges themselves have distinctively different expectations and orientations on their judicial role (Hanson, 2002, Swanson, 2011).
}

(C) H. José Plug. Informal Logic, Vol. 36, No. 3 (2016), pp. 333-348. 
1. Controller (who checks for the legitimacy of decisions)

2. Settler of disputes (who aims at contributing to a swift and definitive solution of a legal dispute)

3. The alternative mediator (who aims at contributing to the solution of a non-legal difference of opinion)

In legal literature on the New approach to case proceedings, many authors (Marseille, 2009, 2010 and Verburg, 2013, among others) focus on the changes pertaining to the judge's role in court hearings. This focus seems obvious, since the effects of the guidelines that followed from the 'New approach' are considered most far-reaching for the performance of the judge during court hearings. According to Verburg and Schueler (2014, p. 68), the 'New approach' entails a major shift from the judgment, the judicial decision, to a focus on the oral hearings. In their view, this new approach 'causes a parallel shift from the state of the art (of) legal craftsmanship to communicative skills as well.' This does not mean, however, that these communicative skills (including argumentative skills) are of exclusive importance to oral court hearings. The judicial decision, as Verburg and Schueler (2014, p. 65) recognise themselves, is an important aspect of the 'New approach' as well. From this perspective, I will focus on the way in which the administrative judge's complex role may be reflected in the judicial decisions he brings forward.

\section{Manifestations and implications of the complex role of the judge}

If the judge's efforts during court hearings do not result in an agreement between the parties involved and therefore proceedings need to be continued, the judge may make yet another attempt to contribute to the solution of the legal dispute as well as the non-legal dispute in his decision. On the basis of analyses of examples of administrative judicial decisions published after the introduction of the New approach to case proceedings, I will demonstrate the argumentative means the judge may exploit to establish the role of alternative mediator in non-legal differences of opinion, apart from the role as an authority who check decisions for their legitimacy. I will analyse these examples using the pragma-dialectical instrument including the notion of strategic manoeuvring. The basic assumption is that the judge, when manoeuvring strategically in his ruling, aims at making an opportune choice from the topical potential of what may be brought up for discussion and that he aligns his argumentative 
contributions to the expectations and frame of reference of the general public and makes effective use of presentational devices as well (van Eemeren, 2010, pp. 93-96). However, in doing so the judge should maintain a balance between effectiveness and reasonableness. This means that gaining rhetorical profit should not hinder the process of resolving the difference of opinion.

In Plug (forthcoming), I have discussed examples of argumentative choices in judicial decisions which could be considered as strategic manoeuvres by the judge in his role as a settler of legal disputes. One of these choices concerns the use of anticipating argumentation. This type of argumentation, often introduced by the phrase 'even if', involves anticipating arguments the party who lost the case or the judge himself could (have) put forward. The argument is part of multiple argumentation by which the judge anticipates the losing party not being satisfied by the part of the complex argumentation that justifies his decision and therefore considering appeal.

In the following example, the judge dismisses an appeal on the grounds that the plaintiff could not prove that he has been an employee of the Brick manufacturing company. By means of anticipatory argumentation the judge refutes a possible objection against this ground for his decision, thus indicating that it is no use for the plaintiff to lodge an appeal against this dismissal and contributes to the finality of the legal dispute.

[...] Even if [the plaintiff] does prove that he has worked in the Brick manufacturing company, he still would not be entitled to receive a work disability benefit (WAO). The law states that you are only entitled to receive a work disability benefit (WAO) if you were an employee at the time that you fell ill.

(Court Amsterdam 11 August 2011

ECLI:NL:RBAMS:2011:BR4880) (Translation by the author)

[...] Ook als [eiser] wel bewijst dat hij bij de steenfabriek heeft gewerkt, dan heeft hij toch geen recht op een WAO-uitkering. In de wet staat dat je alleen recht kunt hebben op een WAO-uitkering als je op het moment dat je ziek wordt werknemer bent.

(Rechtbank Amsterdam 11 August 2011

ECLI:NL:RBAMS:2011:BR4880)

In the following section I will first concentrate on argumentative choices which could be considered as strategic manoeuvres by the judge in his role as alternative mediator. Then I will discuss

(C) H. José Plug. Informal Logic, Vol. 36, No. 3 (2016), pp. 333-348. 
the implications these observations may have for the characterisation of the communicative activity type of administrative judicial decisions by the district court.

\section{Strategic manoeuvring by the judge as alternative mediator}

Analyses of administrative judicial decisions show that decisions which aim at solving an underlying, non-legal difference of opinion, take the shape of an advice or recommendation. These recommendations are put forward by the judge in his role as alternative mediator. Since judges do not usually assume that parties accept their recommendations as a matter of course, they will put forward arguments in support of these recommendations. From a pragma-dialectical point of view, the recommendation should, therefore, not be considered as a directive speech act but as an assertive speech act by means of which the judge expresses a positive or a negative standpoint. When clinching matters in cases like these, judges cannot derive authority from the law. These standpoints, unlike standpoints put forward by a judge in his role as controller of the law or as settler of disputes should, therefore, not be analysed as an assertive-declarative speech act. The propositional contents of the standpoint underlying the judge's advice could, first of all, refer to the acceptability of an intrinsic advice (x). In a case like this the standard form is: the advice to (not) do (x) is acceptable. Secondly, the proposition could refer to a procedural advice (y): the recommendation for parties to find an alternative solution for their dispute. In this case the standard form would be: the advice to do (y) is acceptable.

Apart from the standpoint in relation to a non-judicial disagreement, a judicial decision always puts forward a standpoint referring to the judicial dispute as well. In cases like these, therefore, there is always a multiple difference of opinion. Within the context of the non-judicial disagreement, the judge, in his role as alternative mediator, is the protagonist of the (main) standpoint. Within the context of the judicial dispute, the judge, in his role as settler of disputes or the one to control legitimacy, is the protagonist of the (main) standpoint.

In British and English judicial decisions, for instance, the different roles of judges may be expressed by alternating direct references in the form of the singular or plural personal pronouns 'I' or 'we' with using references in the third person singular, 'the court'. Kaehler (2013, p. 17) demonstrates that various references to judges offer the opportunity to distinguish, in the 
decision, between the judges' standpoints and arguments in 'their private role as citizens' and in 'their official role as judges'.

In Dutch, as well as in German and French law, for instance, the (administrative) judge will always refer to himself in the third person: both the single-judge section and the threejudge section refers to itself as 'the court' (Verburg, 2008, p. 208). The administrative judge, therefore, will have to apply different verbal means to express the fact that, in addition to implementing the law, he also puts forward arguments and a standpoint in his role alternative mediator.

Judges often employ the obiter dictum ('additional consideration') to indicate that the argumentation which they bring forward does not relate to a judicial standpoint. The phrase 'additional consideration', in pragma-dialectics, is regarded as an indicator of multiple argumentation (van Eemeren et al, 2007). In judicial contexts, however, the use of the 'additional consideration' is not quite so unequivocal (Plug, 2000a, p. 190). If argumentation is put forward, the arguments do not always support the judicial dispute at hand. The judge can make use of this ambiguity to bring forward argumentation for his standpoint as alternative mediator. The following may serve as an example of such a manoeuvre.

In a dispute over a building permit for temporary accommodations for a school in the Municipality of Velsen, the administrative judge decides to accept the objections of the plaintiffs. The decision of the municipality to grant a provisional exemption from a zoning plan for the purpose of temporary accommodation is not to be maintained. The fact of the matter is that the municipality, the defendant, has failed to demonstrate the temporariness of the schoolrooms. The judge, in his decision, puts forward the following considerations.

The judge deciding on the statutory provision sets store to, quite superfluously, considering the following. (...) The location at [address A] proposed by plaintiffs by means of temporary accommodation would, in case that particular location were to be given a permanent character, mean teaching children next to a building site and can hardly be taken seriously. Neither do alternative locations passed in review during court hearings stand out for their attractiveness compared to the one chosen today. If plaintiffs are also concerned about the interests of the pupils and their parents - and they are, as appears from their attitude during court sessions - it would show flexibility if they, the outcome of these proceedings notwithstanding, would demonstrate the willingness to refrain from per- 
manently dropping the location at [address B] from their list. (...)

(Court Haarlem 28 February 2011,

ECLI:NL:RBHAA:2011:BP6223) (Translation by the author)

de voorzieningenrechter [hecht] eraan nog het volgende, geheel ten overvloede, te overwegen. (...) De door eisers geopperde locatie aan [adres] - tijdelijke huisvesting aldaar als blijkt dat die locatie de definitieve locatie gaat worden - betekent onderwijs naast een bouwput en kan nauwelijks serieus worden genomen. Ook de andere mogelijke locaties die ter zitting de revue zijn gepasseerd blinken niet uit door grotere aantrekkelijkheid dan de thans gekozen locatie. Indien eisers zich mede de belangen van de kinderen en hun ouders aantrekken - en blijkens hun opstelling ter zitting zijn ze begaan met die belangen - zou het getuigen van flexibiliteit indien zij, niettegenstaande de uitslag van deze procedure, de bereidheid zouden tonen de locatie aan de [adres] niet definitief van het lijstje te schrappen. (...)

(Rb. Haarlem 28 februari 2011, ECLI:NL:RBHAA:2011:BP6223)

The phrase 'quite superfluously, considering' used by the judge in this fragment indicates that what follows does not refer to the preceding judicial standpoint. The provision is even intensified by the word 'quite'. The communicative status of each of the following speech acts is, however, not entirely clear. Nevertheless, it becomes apparent that the judge creates an opportunity to continue his argument in his role as alternative mediator. Although the label obiter dictum ('additional consideration') is not an exclusive indicator for argumentation, consecutive speech acts should be regarded as argumentative. The speech acts consist of arguments brought forward by the judge in support of his standpoint that 'plaintiffs [should] demonstrate the willingness to refrain from permanently dropping the location at [address B] from their list.' His attempts to convince parties of the acceptability of his intrinsic advice (to not do $\mathrm{x}$ ), 'the outcome of these proceedings notwithstanding', could be interpreted as an attempt on the judge's part to contribute, in the context of his judicial decision, to the settlement of the underlying conflict between parties.

The following example demonstrates that the judge's may be a twofold advice: he provides an intrinsic advice (to do $\mathrm{x}$ ) as well as a procedural advice (to do y). In this case the dispute 
between a citizen of the town Boxtel, the plaintiff, and the city council of Boxtel, the defendant, concerns the rejection of the plaintiff's request to take action against noise caused by an air conditioner placed on their neighbour's roof. A license to place the air conditioner has been suspended by the defendant. The court determines on the grounds of a research by experts, that the noise level of the air conditioner is kept within the noise limit. Accordingly, the court decides that the defendant does not need to take action against the neighbour's air conditioner. In the decision the court brings forward the following.

Apart from this case, the court finds reason, in the dispute between the plaintiff and [name A], to remark the following. (...) It seems to the court, that the air conditioner can easily be replaced. This replacement will of course involve expenses. Considering that both parties, in view of their disturbed relationship, benefit from a solution in this conflict, the court deems it entirely reasonable for the plaintiff to contribute to the costs of the replacement. The court urges the plaintiff and [name A] and their proxies to once again try to come to an amicable solution, in the knowledge that the administrative law cannot offer a solution to problems between neighbours, such are at issue here.

(Court 's-Hertogenbosch, 14 December 2012, ECLI:NL:RBSHE:2012:BZ0544) (Translation by the author)

de rechtbank [ziet] aanleiding om, los van deze zaak, met betrekking tot het tussen eiser en [naam A] bestaande geschil, het volgende op te merken. (...) Het komt de rechtbank voor dat de installatie dan ook zonder problemen kan worden verplaatst. Deze verplaatsing gaat uiteraard met kosten gepaard. In aanmerking nemende dat beide partijen, gelet op de op dit moment verstoorde relatie, baat hebben bij een oplossing, acht de rechtbank het alleszins redelijk dat eiser bij verplaatsing van de installatie bijdraagt in de kosten daarvan. (...). De rechtbank dringt er bij eiser en [naam A] en bij hun gemachtigden op aan om opnieuw te trachten een oplossing in der minne te bereiken, in de wetenschap dat het bestuursrecht voor problemen tussen buren, als hier in het geding, geen bevredigende oplossing kan bieden.

(Rb. 's-Hertogenbosch 14 december 2012, ECLI:NL:RBSHE:2012:BZ0544) 
In this fragment, the judge uses the formulation 'apart from this case' and the expression 'to remark' to indicate that what follows should not be interpreted as part of the justification of the legal standpoint that has been provided above. Despite the indication that what follows should be interpreted as remarks, the judge presents in fact argumentation for the acceptability of both an intrinsic advice as well as for a procedural advice. The argumentation that can be reconstructed as being in support of the acceptability of the judge's (intrinsic) advice for the plaintiff to contribute to the costs of the replacement consists of that it would be reasonable to do so because both parties benefit from the replacement. The argument that the administrative law cannot offer a solution to the problem may be reconstructed as support for the acceptability of the (procedural) advice to try to come to an amicable solution.

\section{Implications of the judge's changing role for the activity type}

The above examples demonstrate that a judge who has perceived a non-legal difference of opinion that cannot be solved during the court hearing, can make a final attempt to successfully contribute to the settlement of this conflict in the administrative judicial decision. If these attempts have to be regarded as part of the altered institutional demands, this would have the following consequences for the characterization of the activity type of judicial decisions by the administrative (district) court.

\begin{tabular}{|c|c|c|c|}
\hline $\begin{array}{l}\text { domains of } \\
\text { communi- } \\
\text { cative } \\
\text { activity }\end{array}$ & $\begin{array}{l}\text { general genres } \\
\text { of communica- } \\
\text { tive activity }\end{array}$ & $\begin{array}{l}\text { specific } \\
\text { communicative } \\
\text { acdtivity types }\end{array}$ & concrete speech event \\
\hline $\begin{array}{l}{[=\text { more or }} \\
\text { less institu- } \\
\text { tionalized } \\
\text { macro- } \\
\text { contexts }]\end{array}$ & $\begin{array}{l}{[=\text { families of conven- }} \\
\text { tionalized communi- } \\
\text { cative practices }]\end{array}$ & $\begin{array}{l}\text { [= subtypes of } \\
\text { conventionalized } \\
\text { communicative } \\
\text { practices] }\end{array}$ & $\begin{array}{l}\text { [= instantiations of } \\
\text { communicative activity } \\
\text { types }]\end{array}$ \\
\hline \multirow[t]{3}{*}{$\begin{array}{l}\text { legal } \\
\text { communi- } \\
\text { cation }\end{array}$} & & $\begin{array}{l}\text { Judicial decisions by the } \\
\text { (District) Court (Admin- } \\
\text { istrative Law) }\end{array}$ & $\begin{array}{l}\text { Dutch judicial decision } \\
\text { [by the }\{\text { District) Court } \\
\text { Utrecht } 21-12-2012]\end{array}$ \\
\hline & \multicolumn{3}{|c|}{ (Multiple institutional points) } \\
\hline & adjudication & \multicolumn{2}{|c|}{$\begin{array}{l}\text { (1). Providing a binding decision in a difference of } \\
\text { opinion about whether acitizen is being treated unlaw- } \\
\text { fully by the actions of an administrative authority }\end{array}$} \\
\hline
\end{tabular}

(C) H. José Plug. Informal Logic, Vol. 36, No. 3 (2016), pp. 333-348. 


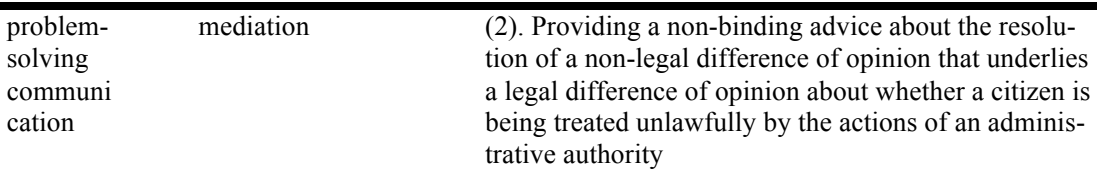

Figure 2. An example of a representation of a hybrid activity type

In contrast with the traditional activity type, the institutional point should considered to be multiple. Next to the traditional institutional point of providing a binding decision in a difference of opinion about whether a citizen is being treated unlawfully by the actions of an administrative authority, the second institutional point may be formulated as providing a non-binding advice about the resolution of a non-legal difference of opinion that underlies a legal difference of opinion. As a consequence these decisions are to be characterized as a hybrid activity type in which problem-solving communication is incorporated in the domain of legal communication.

\section{Conclusion}

Developments in administrative law have resulted in a more complex role to be played by administrative judges. The judge no longer only assesses the legitimacy of decisions made by administrative authorities, but is expected to also actively apply every possibility to achieve a final settlement of the judicial dispute as well as the underlying conflict. Beside his role as the judge who applies the law or assesses the legitimacy of administrative decisions, a distinction should be made between two additional roles: the one of settler of disputes and the one of alternative mediator.

Ever since the introduction of the New approach to case proceedings [the Nieuwe zaaksbehandeling] attention for the changing role of the judge has been mainly focussed on his performance during court hearings. On the basis of examples of administrative justice I demonstrated that the increasingly complex roles judges play may also be expressed in judicial decisions. By means of strategic choices as to the presentation of arguments put forward in judicial decisions, the judge can contribute to the solution of the judicial dispute as well as to the underlying, non-legal conflict. By making use of the possibility, within a judicial decision, to put forward a non-legal standpoint, beside a judicial standpoint, by way of advice or recommendation, and in doing so interpreting the dispute as a multiple difference of opinion, the judge, in his role as alternative mediator 
may contribute to the settlement of the non-legal conflict between parties. Subsequently, I have shown that interpreting the altered institutional demands not only applicable to the court hearing but also to the judicial decision, implies that decisions by the administrative (district) court should be characterised as a hybrid activity type that aims to realise multiple institutional points. This characterization may function as a starting point for research on argumentative patterns in hybrid legal activity types such as administrative rulings.

Acknowledgement: This article is based on the author's paper presented at the European Conference on Argumentation (ECA) in Lisbon, June 2015.

\section{References}

Eemeren, F. H. van \& B. Garssen (2013). Argumentative patterns in discourse. OSSA Conference Archive. Paper 42.http: //scholar.uwindsor./ossaarchive/OSSA10/papersandcomment aries $/ 42,1-15$.

Eemeren, F. H. van, P. Houtlosser \& A.F. Snoeck Henkemans (2007). Argumentative Indicators in Discourse. A PragmaDialectical Study. Dordrecht: Springer.

Eemeren, F. H. van en P. Houtlosser (2006). Strategisch manoeuvreren, het model van een kritische discussie en conventionele actietypen. Tijdschrift voor Taalbeheersing, 28, nr. 1, $1-14$.

Eemeren, F. H. van (2010). Strategic maneuvering in argumentative discourse. Extending the pragma-dialectical theory of argumentation. Amsterdam/Philadelphia: John Benjamins.

Eindrapport Project Differentiatie van werkstromen Bestuursrecht (2010). www.rechtspraak.nl/Organisatie/PublicatiesEn-Brochures/rapporten-en-artikelen.

Feteris, E.T. (1989). Discussieregels in het recht. Een pragmadialectische analyse van het burgerlijk proces en het strafproces. Dordrecht: Foris.

Hanson, R. (2002). The Changing Role of a Judge and Its Implications. Court Review, 10-16.

Kaehler, L. (2013). First-Person Perspectives in Legal Decisions. Law and Language, Vol. 15, 1-32.

Kloosterhuis, H.T.M. (2002). Van overeenkomstige toepassing: de pragma-dialectische reconstructie van analogieargumentatie in rechterlijke uitspraken. Amsterdam: Thela Thesis. 
Marseille, A.T. (2007). De bestuursrechter en diens vrijheid. Van actief naar lijdelijk (en weer terug). Trema, nr. 10, 423431.

Marseille, A.T. (2009). De zitting bij de bestuursrechter. Een onderzoek naar het belang van de zitting voor een adequate afdoening van bestuursrechtelijke beroepsprocedures. Den Haag: Boom.

Marseille, A.T. (2010). Effecten van informalisering van bestuursrechtspraak. NTB, 8, 221-229.

Plug, H.J. (2000). In onderlinge samenhang bezien. De pragmadialectische reconstructie van complexe argumentatie in rechterlijke uitspraken. Amsterdam: Thela Thesis.

Plug, H.J. (2000a). Indicators of obiter dicta. A pragmadialectical analysis of textual clues for the reconstruction of legal argumentation. Artificial Intelligence and Law. Vol. 8, Issue 2-3, 189-203.

Plug, H.J. (2015). Transparency in legal argumentation: adapting to a composite audience in administrative judicial decisions. In F.H. van Eemeren \& B. Garssen (Eds.), Scrutinizing Argumentation in Practice (Argumentation in Context, 9). (pp. 121-132). Amsterdam: John Benjamins.

Plug, H.J. (forthcoming) Argumentative contributions to the settlement of conflicts in administrative judicial decisions. In Legal Argumentation and the Rule of Law.

Polak, J.E.M. (2010). Veranderende perspectieven van de bestuursrechter. In: Barkhuysen T., Ouden W. den \& Polak J.E.M. (red.), Bestuursrecht harmoniseren: 15 jaar Awb. (pp. 97-110), Den Haag: Boom Juridische uitgevers.

Swanson, R.A. (2011). Judicial Roles in State High Courts. Judicature, Vol. 94, no. 4, 169-177.

Verburg, D.A. (2008). De bestuursrechtelijke uitspraak - en het denkmodel dat daaraan ten grondslag ligt. Zutphen: Uitgeverij Kerckebosch.

Verburg, D.A. (2013). De nieuwe zaaksbehandeling van de bestuursrechter. Tijdschrift Conflicthantering, 3, 19-23.

Verburg, D.A. \& B. Schueler (2014). Procedural Justice in Dutch Administrative Court Proceedings. Utrecht Law Review, Vol. 10, issue 4, 56-72. 